\title{
Members Are Not the Only Fruit: Volunteer Activity in British Political Parties at the 2010 General Election ${ }^{1}$
}

\author{
Justin Fisher (Brunel University), Edward Fieldhouse (University of Manchester) \& David \\ Cutts (University of Bath)
}

Key Words: Party Members; Party Supporters; Party Decline; Election Campaigns

\begin{abstract}
Existing research on volunteer activity in political parties has tended to focus on party membership, both in terms of numbers and activities undertaken. Recent developments in British political parties suggest however, an increasing role for party supporters - supporters of parties who are not formal members. Using data collected through surveys of election agents at the 2010 general election, this article examines the extent of supporter activity in constituency (district-level) campaigns, the extent to which active local parties stimulate supporter activity, the correlates of supporter and member activity, and whether supporter activity makes a positive and independent contribution to parties' constituency campaigns. The article provides an important opportunity to question whether the evolution of party organisations suggests that formal members may be less important than has been previously assumed in the conduct of election campaigns and the extent to which supporter activity complements that of members.
\end{abstract}

\section{INTRODUCTION}

Existing research on volunteer activity in political parties has focussed for the most part on party membership, both in terms of numbers and activities undertaken. Studies of the health of political parties often draw upon membership levels and their decline as an indicator of some form of malaise in political parties (see, for example, Mair \& van Biezen, 2001; van Biezen, Mair \& Poguntke, 2012), even if, as Webb (1995) and Katz \& Mair (2009) have pointed out, there are many more nuanced ways of evaluating such questions.

Notwithstanding these interventions, the message in much research has been clear: formal party membership is the appropriate indicator of volunteer activity within political parties, and that metric is in decline (and has been so for some time). This is taken as an indication that political parties as we understand them are in some form of crisis (Mair \& van Biezen, 2001; Whiteley, 2011; Lawson \& Merkl, 1988). Indeed, as van Biezen, Mair and Poguntke (2012: 40) suggest, party membership levels may have fallen to such a low level that membership 
may no longer represent a meaningful indicator of party organisational capacity, or indeed that the decline in membership may be such that party organisation itself may no longer be a relevant indicator of party capacity.

This message is broadly reflected in Seyd and Whiteley's path-breaking studies of party membership in Britain (Seyd \& Whiteley, 1992; Whiteley, Seyd \& Richardson, 1994; Seyd \& Whiteley, 2002; Whiteley, Seyd \& Billinghurst, 2005). Their studies illustrated not only the importance of volunteer activity in electoral terms through the mobilization of the votes, but also in terms of varying key roles that members play in the life of political parties: selecting candidates and leaders, forming the population from which candidates are selected, being the parties' representatives on the ground, engaging in political communication, and being involved in policy and campaign initiation (see also Scarrow, 1996; Maor, 1997). Yet, these studies also suggested that such activities were not always widespread within parties and that much party activity was in decline. As such, this presented a problem for political parties.

Denver, Hands and Fisher (1997, 2003, 2006a, 2006b) have also focussed almost exclusively on party members as the source of voluntary activity in constituency (districtlevel) campaigns in Britain. Where volunteers were recruited from outside the constituency party, the assumption was that these people were party members from a neighbouring constituency. Fisher and Denver's $(2008,2009)$ analyses also showed that party membership was in broad decline, but offered a less pessimistic interpretation. They showed how advances in technology and its falling relative cost were increasingly being used as a substitute for traditional activity by all parties. Moreover, they questioned the assumption that having more members was always electorally beneficial; showing that central party management of campaigns frequently had stronger electoral effects (Fisher, Denver \& Hands 2006a). Scarrow (2000: 95), too points out that the size of a party's membership may not necessarily be linked to the level of individual activity. Fisher and Denver (2009) do, however, also show that voters tended to respond more positively to more traditional campaign methods which were associated with volunteer labour, rather than more modern techniques which could be used without such intensive volunteer help (though that gap is diminishing). Moreover, Fisher (2011) shows that 'free' forms of campaigning (which are exclusively based on volunteer activity) are generally more electorally effective than 'costed' campaigning - techniques that cost money including traditional items like leaflets and posters, and more modern ones like telephones and computers. Nonetheless, volunteer activity in all these studies was assumed to have been provided by members. 
Comparative research, however, suggests that the strong emphasis on formal individual members - or the 'party on the ground' (Katz \& Mair, 2009: 756) - may be provide an incomplete picture. Most obviously, the parties in the United States bear little relation to European parties in terms of members. As Katz and Kolodny (1994: 31) point out, party affiliation on the electoral register means that parties have no control over registration and cannot impose any requirements or expel affiliates for disloyalty. And, of course, affiliates pay no party dues. In US presidential parties ' ... there are no party members in any real sense' (Katz and Kolodny, 1994: 35). Similar arrangements, involving non-party members in candidate selection through primaries have been observed in Taiwan, Mexico and Italy (Hazan and Rahat, 2010: 39-40; van Biezen, Mair \& Poguntke, 2012:39-40). And, in 2011, the French Socialist Party used a primary system to select its Presidential candidate. Voting was open to any French adult who signed a pledge that they support the 'values of the left'. A fee of $€ 1$ was levied on each voter. ${ }^{2}$ These examples of primaries would appear to confirm a wider trend suggested by Katz \& Mair (2009: 761) of 'an erosion of the boundaries between formal members and supporters'.

Others also point to isolated examples of non-member party activity. Historically, Ware (1996: 65-69) shows that both cadre and mass parties had supporters who were willing to carry out some party tasks, while Dalton (1996) shows that in Germany, 'campaign activity extends beyond formal party members to include a significant proportion of the public' (p.48). Scarrow (1996: 198-201) additionally points out that the SPD and CDU in (West) Germany began moving towards greater 'inclusiveness' - allowing non-members a greater say in party affairs - from the early 1970s. Indeed, both the CDU and SPD encouraged local parties to allow non-members to stand as candidates, though party supporters were still prevented from participating in intra party votes. Likewise, the Italian Communist Party also included non-party members as candidates (Hazan \& Rahat: 2010: 53) and the Catalan Socialist party permits registered 'sympathisers' to participate in party elections (Hopkin (2001: 348).

In sum, the various examples above suggest that an exclusive focus on members may indeed present a potentially misleading picture in respect of party activity and perhaps, party health. This article therefore seeks to assess how far supporters are involved in political parties focussing on a key and core area of party activity, election campaigning. To examine this further, we focus our attention on Britain, where recent changes suggest a number of moves to involve supporters (non-members) in party activities, and where extensive new data collected at the $\mathbf{2 0 1 0}$ general election are available, allowing us to assess the extent of

http://www.bbc.co.uk/news/world-europe-15201158 (Accessed 15/11/11) 
supporter activity in election campaigns. These data are drawn from a survey of electoral agents of all candidates of the Conservative Party, Labour Party, Liberal Democrats, Scottish National Party and Plaid Cymru standing in seats in Great Britain, conducted immediately after the 2010 general election. ${ }^{3}$ All candidates are required by law to have an election agent. Agents are responsible for the organisation and conduct of campaigns and are the most accurate source of information on the conduct of campaigns. The numbers of responses are shown in the Appendix. In addition, a small number of in-depth qualitative interviews were conducted with a sample of electoral agents in the weeks following the election.

\section{CHALLENGES TO NOTIONS OF PARTY MEMBERSHIP IN BRITAIN}

The first key question for this article is whether the strong focus on formal members is obscuring the party activity of non-members as a number of isolated examples in other countries suggest. In one sense, Labour's party structure, which includes affiliated trade unions, suggests that an exclusive focus on formal individual members could be missing something. Members of affiliated trade unions are themselves affiliated members of the party, though are frequently not formal members in any meaningful sense, despite the efforts of the Labour Party to boost individual membership among affiliated union members in the 1980s and 1990s (Russell, 2005: 218-9). Seyd \& Whiteley's (1992:35) study of Labour members showed for example that while $64 \%$ of Labour members were in a trade union in 1989 , large numbers were from non-affiliated unions. By 1997, only $34 \%$ of Labour members were trade unionists and the authors concluded that 'at its grassroots, the Labour Party is now neither a working class nor a trade union party' (Seyd \& Whiteley, 2002: 35-7). Nonetheless, affiliated members could be a source of volunteer labour for the party. In the 2001 study of constituency campaigning, some questions were asked on this topic (Denver, Hands \& Fisher, 2001). The responses suggested that there were indeed some supporters who came to Labour's campaign via affiliated unions - $13 \%$ of Labour constituencies reported receiving a good deal of help from locally affiliated unions. But equally, some $64 \%$ reported receiving no help from regional liaison committees and nearly $50 \%$ had no help from affiliated local unions. Where help was given, it was mainly financial (18\%) and help with printing (18\%). In terms of supporters, relatively few constituencies received help with distributing leaflets (17\%) and telephone canvassing (13\%). 
The concept of Labour Party membership has itself also become subject to fewer preconditions. Prior to reforms instigated by former leader, Neil Kinnock, membership of the Labour Party was handled with varying degrees of success by constituency Labour parties. There was a formal (if not always observed) requirement that members should belong to a trade union. Kinnock's reforms transferred membership to the central party and thus enabled people to join the party by by-passing local activists (Russell, 2005: 218) and relaxing the trade union membership requirement. The concept of membership, therefore, had become a little less formal and moves in the mid-1990s, such as 'recruit a friend' continued this trend (Russell, 2005:220). Ironically, there has been similar change in the Conservative Party, though in the opposite direction. Hitherto, membership of the Conservative Party had been a rather vague concept, with no set membership fee (Whiteley, Seyd \& Richardson, 1994: 72; Maor, 1997: 118-9). The basis of Conservative membership is now more akin to that of Labour - centralised membership with a fixed fee.

However, despite the main parties uniting around a broadly common approach to individual party membership (the Liberal Democrats have broadly similar arrangements), Fisher (2008) highlights four developments that suggest that supporters (but non-members) are becoming more involved in party activities. Firstly, in Labour's organisational reforms of 1996/1997 (Partnership in Power), non party members were permitted to have input into the policy making process at the stage of the policy commissions (Fisher, 2002). Secondly, in recent years, Labour, the Conservatives and the Liberal Democrats have established supporter networks, which have focussed principally on publicity and campaigning (Guaja, 2009). Labour has gone further, with serious internal debates regarding the incorporation of supporters into the activities more usually reserved for traditional members (Horton et al, 2007). This culminated in the consultation paper Refounding Labour (2011a), which highlighted a number of key roles for supporters. This article acknowledged that the party has many supporters 'who might have joined in previous times' (p.11) and that those supporters can be a crucial source of labour in election campaigns (p.12). But it goes further, floating the idea of supporter involvement in party policy making (p.17) and even leadership elections (p.24). The subsequent Refounding Labour to win (2011b) endorsed the idea of involving supporters more formally in the Labour Party and at the 2011 Labour conference, it was announced that supporters would be given between $3 \%-10 \%$ of the votes in the party's next leadership election provided that 50,000 supporters were recruited. 
The third development is the Conservatives' experiments with primaries for candidate selection ${ }^{4}$. The first Conservative candidate elected after selection through an open primary became an MP in 2005 (in Reading East) (Mcllveen, 2009), while in Totnes, the Conservative candidate for the 2010 election was selected through a postal ballot of all voters in the constituency (an arrangement celebrated in a subsequent report on candidate selection by the Institute for Government in 2011). Finally, the Hayden Phillips review of party finance (2006) recommended the encouragement of web-based contributions that would attract a degree of matching funding. This effectively proposed an institutionalized mode of party activity for non-members.

All four developments represent to varying degrees both a challenge to the idea of membership as the principal basis of voluntary support for parties, and a challenge to the traditional power of party members. It also suggests that many of the roles of members outlined by Seyd and Whiteley may now not be their exclusive preserve. The use of primaries, for example, means that supporters can play a role in the selection of candidates, as well as potentially providing a pool from which candidates can be selected - some of the Conservative 'A list' candidates were only very recent formal members of the party. Equally, Labour's reforms and proposed reforms suggest that non-members can also play a role in policy initiation and leadership selection. And, of course, supporters can become involved in election campaigns, assisting with the mobilization of the vote and political communication.

All in all, the British case and other examples cited above suggest that a focus on members as voluntary participants in party activity is incomplete. Moreover, if supporter involvement is extensive, it may indicate that the use of membership as a metric to indicate party decline could potentially present a misleading conclusion. In other words, party strength measured by formal membership may indicate decline, but supporter activity may indicate greater party evolution. Thus, if the incorporation of supporters into party activities is widespread, this may suggest that the negative effects associated with membership decline may be partially offset.

In order to assess this further, the next section of this article examines member and supporter activity at the 2010 General Election. Election work generally represents the most prevalent form of voluntary party activity in Britain. Seyd and Whiteley show, for example,

The Conservatives' use of primaries was viewed as novel. However, it is worth making reference at this point to a book published in 1967, which argued strongly for the introduction of primaries for the major British parties. Peter Paterson (1967: 183) argued that '...we have two great political parties which are evidently dying on their feet. By whatever standard one judges them, either as electoral machines or as instruments for involving the people in government and keeping government in touch with the feelings and aspirations of the people, they have failed....they manage to attract fewer people to the polls at succeeding General Elections. Their own membership is declining.' 
that members of the Labour and Liberal Democrat parties are much more likely to undertake activities such as delivering election leaflets than attend party meetings (Seyd \& Whiteley, 2002: 82; Whiteley et al, 2006:72). Amongst Conservative members, activity is slightly less election focussed, but still represents a core activity (Whiteley et al, 1994:258). Elections are, therefore, a key aspect to examine when evaluating the roles and activities of supporters and members in political parties.

\section{MEMBERS AND SUPPORTERS AT THE 2010 BRITISH GENERAL ELECTION}

Political parties have traditionally relied on members to participate in election campaigns. In addition to their enthusiasm and commitment to the party's goals, members provide a source of free, volunteer labour, which can be drawn upon to engage in doorstep canvassing, delivering leaflets, taking numbers at polling stations, 'knocking-up' voters on polling day and so on. Without party members it would be almost impossible to run a traditional constituency campaign focused on identifying supporters and mobilising them on polling day. Indeed, while Fisher et al. (2006a) argue that simply having a large number of members is no guarantee of an effective campaign (cf. Whiteley \& Seyd 2003), they concede, nonetheless, that a campaign involving relatively few members is likely to be less successful than one that can call upon a large volunteer force.

However, as has been well documented, party membership in both Britain and in other European countries is in decline and this is one contributory factor in the relative decline of more traditional campaigning as well as campaigning that can be conducted at no cost (Fisher \& Denver, 2008; Fisher, 2011). Although increasing use has been made of more modern and increasingly cheap techniques to compensate partially for the decline of members, the problem for parties is that voters appear to respond better to more traditional, labour-intensive techniques (Fisher \& Denver, 2009). This leaves parties with a dilemma traditional techniques seemingly deliver more electoral benefits, but parties are increasingly unable to mount such campaigns using party members alone.

However, new data from the 2010 general election suggest that parties have also looked to non-party members (supporters) to help with campaigns. Table 1 illustrates the importance of party supporters. Overall, in the 2010 election campaign, some $78 \%$ of local Conservative, Labour and Liberal Democrat parties recruited some supporters to help with the campaign - 
a mean of 18 supporters per constituency. ${ }^{5}$ To put this figure in some context, a separate question asked how many campaign workers were involved towards the end of the campaign. This figure will almost certainly be lower than the total number of campaign workers involved overall, since some activity will be greater at the outset and will wind down as polling day approaches, especially in 'hopeless seats' - seats where a party has almost no chance of victory. Nevertheless, the mean number of campaign workers for local Conservative, Labour and Liberal Democrat parties involved towards the end of the campaign was 28 .

Of the three main parties, the Liberal Democrats were most likely to recruit supporters (fully $86 \%$ did so). This higher level of supporter recruitment by the Liberal Democrats may not be a surprise. The party has a traditional and ideological commitment to the local, frequently expressed through community politics, which may manifest itself through campaigns on less overtly political themes. Whiteley et al (2005: 98-100) show, for example, that many Liberal Democrat members are also embedded in local community organisations, thus providing the opportunity to recruit like-minded local activists to assist the party without actually joining it. This is made easier by similar ideological structuring of both Liberal Democrat members and voters (Whiteley et al, 2005: 65).

Overall then, supporter activity in these election campaigns was clearly widespread. The question that flows from this finding is whether the activities of supporters simply complement those of members (contributing something which emphasizes existing activities), or whether they also supplement them (adding something extra which enhances the activities). We assess this by applying four key tests to assess the degree of similarity between supporter and member activities.

1. To what extent do supporters engage in similar activities to those of members?

2. To what extent is supporter activity a function of existing active local parties?

3. Are the levels supporter activity predicted in a similar way to levels of member activity?

4. Do supporters make an independent positive contribution to constituency campaigns?

In a small number of cases (16), the reported number of supporters declared was considered to be unreliable, being far in excess of the total number of campaign workers and adversely distorting the mean. As a result, all cases where the declared number of supporters was in excess of 200 , the cases were removed from the analysis. This represented 3 Conservative cases, 1 Labour and 12 Liberal Democrats. As a result, the mean number of supporters may be a slight underestimate. 


\section{[Table 1 About Here]}

\section{TO WHAT EXTENT DO SUPPORTERS ENGAGE IN SIMILAR ACTIVITIES TO THOSE OF MEMBERS?}

Our first question is the extent to which the activities that supporters engage in are similar to those of party members. Seyd and Whiteley $(1992,1994,2005)$ differentiate between different kinds of activism - low and high intensity. Thus, activities such as delivering leaflets are low intensity, while voter contact (either on the doorstep or by telephone) is regarded as high intensity. We would expect, therefore, that members would be more likely to be involved in high intensity campaigning, while supporters might be more focussed on low intensity work. Of course, low intensity does not imply low impact - especially in an election like 2010 where the distribution of literature was such a core part of all parties' campaigns (Fisher Cutts \& Fieldhouse, 2011a).

We examine these questions in more detail in Tables $2 \mathrm{a}, 2 \mathrm{~b}$ and $2 \mathrm{c}$, comparing the activities of supporters, members in seats where supporters were recruited, and all members. First, we examine aggregate percentages. The fairest comparison between members and supporters is in seats where supporters were recruited since these are likely to be areas of relatively greater overall activity (columns 2 and 3 in the tables). The evidence is mixed but pretty consistent across parties. On the one hand, it is clear that to some extent, party supporters engaged to varying degrees in the same activities as party members, and in the case of delivering leaflets (the activity in which all parties made most effort), to a virtually identical degree. Equally, supporters were quite likely to staff polling stations relative to members, and were perhaps surprisingly likely to be involved at the campaign headquarters, despite not being formal members. However, in respect of other activities where voters were contacted either on the doorstep or by telephone, supporters were less likely to be involved than members, as hypothesised. A reason for this is that according to one agent interviewed, some supporters were uneasy about canvassing where they might be asked detailed questions about party policy (even though the principal purpose of canvassing is to identify voters' intentions). In effect, this would suggest that some supporters excluded themselves from such activities rather than parties being necessarily more reluctant to engage supporters in them.

We take this analysis further by examining whether the patterns of participation by supporters are similar to those of members on a constituency by constituency basis. Since the variables are binary measures, we use Phi coefficients as the appropriate measure of 
association. These are shown in the fourth column in the tables. There are both similarities and differences across parties. For all parties, the activity where there is most similarity for all is taking numbers at polling stations. Equally, the activity where there is most dissimilarity between members and supporters is in doorstep canvassing. Beyond that, there are some isolated findings of note. For Labour, there was strong similarity in terms of whether members and supporters were involved in leaflet distribution, while for the Conservatives, all areas except for taking numbers at polling stations suggested different patterns of participation between members and supporters.

\section{[Table 2a About Here] \\ [Table 2b About Here] \\ [Table 2c About Here]}

Overall, party supporters were used to a significant extent across a wide range of campaign activities and largely complemented the lower intensity activities undertaken by members. Parties still need members, and still rely on them more for particular election activities. But at the same time, these data suggest that party supporters would appear to provide a more important source of labour than has previously been appreciated. Qualitative data gathered through face to face interviews with agents would seem to add some weight to this point: one election agent in a target seat said: "Members are almost insignificant compared with the pool of helpers and activists.... [Supporters] don't like committing [themselves] to one political party". Another, also in a target seat, claimed that there were two or three times the number of supporters than members. When asked why those supporters didn't join the party, he indicated that many didn't want to be on lists 'receiving begging letters [for donations]'.

Further comparisons can be made if we create a scale of activities undertaken by members and supporters. This is an additive scale of all the activities in which there was engagement in our list, running from 0 (no activities) to 5 (all five activities). Table 3 examines the mean levels of activity by members and supporters. The findings are as expected - party members engaged in more activities on average than supporters. Thus, Conservative members who were involved in the election in seats where supporters were recruited participated in a mean of 4.1 activities compared with a mean of 2.8 activities undertaken by supporters. Table 3 also illustrates the mean proportion of activities undertaken by supporters compared with members. On average, this was around two thirds of the effort. So, members did on average undertake more in the way of activities, but the contribution of supporters was clearly nontrivial and significantly enhanced all parties' election efforts. 


\section{[Table 3 About Here]}

\section{TO WHAT EXTENT IS SUPPORTER ACTIVITY A FUNCTION OF EXISTING ACTIVE LOCAL PARTIES?}

Supporters, then, are clearly important, but again we want to establish the extent to which supporter activity may be an extension of that of members. In order to do this, we ask a further question: to what extent does existing membership strength provide a stimulus for supporter activity? To address this question, we use two measures of existing membership strength - the level of party membership and the proportion of the constituency covered by an active party organisation. This provides an indicator of both volume and actual activity of the standing party membership. Such measures could have both positive and negative effects on the level of supporter activity (our dependent variable). A high or active membership may be more adept at recruiting and incentivising supporters - complementing the activities of members. Equally, a low or inactive membership may prompt greater activity from supporters in order to compensate. We test the impact of existing membership strength on levels of supporter activity by way of a regression model. The results are illustrated in Table 4 and indicate some interesting patterns.

First, there is clear variation by party. Existing membership strength is a poor predictor of supporter activity in the Conservative and Labour parties, but a better one in the case of the Liberal Democrats. Second, the level of party membership is only significant in the case of the Liberal Democrats. Third, the level of existing membership activity is a positive and statistically significant factor in predicting levels of supporter activity for all three parties, suggesting that members may be of continuing importance. All in all however, the evidence in respect of our question is very mixed. On the one hand, supporter activity was boosted by existing party strength in all three cases, thus suggesting that supporter activities may complement those of members. On the other hand, there is a significant difference between the Liberal Democrats and the other two parties. In the case of the former, there is a stronger case for the complementarity argument - both the size and activity of local parties boosted supporter activity. In the case of the Conservatives and Labour, however, the relationship is very weak. The size of the membership had no impact, while the level of activity had only a very limited one, suggesting supporter activity for these two parties complemented that of the members, but also supplemented it to an extent. 


\section{[Table 4 About Here]}

\section{ARE THE LEVELS SUPPORTER ACTIVITY PREDICTED IN A SIMILAR WAY TO LEVELS OF MEMBER ACTIVITY?}

To address this question, the analysis breaks the predictor variables down into three categories: demographic, politics and party. Demographic correlates are straightforward aggregate predictors of levels of supporter activity - social class, housing, population density, levels of education, ethnicity, and numbers of students. Previous research (Fisher, 2000; Fisher, Denver \& Hands, 2006b) has shown that such variables can be useful indicators of levels of party membership, although the impact of demographics varies somewhat by party.

The category of politics is recognition that political circumstances can be an incentive to greater levels of activity. Previous research has demonstrated, for example, the impact of electoral performance on subsequent levels of party membership (Fisher, 2000; Fisher, Denver \& Hands, 2006b). We might therefore expect this to occur to a certain extent among party members, but to a greater extent among supporters. Given that supporter activity may not be long term, we might expect variations in intensity to be an important function of political conditions. Thus, the prospect of victory or possible defeat in a seat may prompt supporters to be more active.

We capture these circumstances through a series of dummy variables, indicating the main two parties in a constituency contest and which party was the incumbent. In addition to the electoral status of a seat, a candidate's sex or ethnicity may also motivate volunteers. Russell (2005: 225-6), for example, shows that the adoption of women's quotas for candidates by Labour in the 1990s transformed the activist base. We would hypothesise then that candidates from underrepresented groups may be more likely to promote supporter activity, since they may attract activists not traditionally prominent in party politics.

The third category is parties. This variable deals with two core aspects - the level of preparation in the constituency in advance of the election and whether or not the seat was deemed to be a target. Preparation is measured through a scale ${ }^{6}$ designed to capture a key

$6 \quad$ This scale captures levels of preparation with the following when the election was announced: Appoint people to particular jobs; raising campaign funds; location of main committee room; arranging local committee rooms; obtaining 
aspect of good campaign management. Fisher, Denver \& Hands (2006a) have shown how effective management is a core aspect of campaign success and we may hypothesise that a better prepared campaign team will be more able to recruit and engage supporters and members. Second, a dummy variable denoting the target status of a seat is included, since we might expect that parties would seek to encourage more supporter and member activity in their target seats.

Tables 5 and 6 assess the correlates of supporter and membership activity. We include those coefficients that are significant up to the $10 \%$ level for information, though any effects of these variables are clearly very limited. There are similarities and differences for all three parties - for all three, local preparation was a spur for both member and supporter activity. In short, active campaigns require strong organisation. The same is broadly true in terms of targeting. If we accept coefficients significant at the $10 \%$ level, then targeting prompted both member and supporter activity for the Conservatives and Liberal Democrats - especially the latter.

Two political prompts also have similar effects. For Labour, supporter and member activity was higher when defending seats from the Conservatives and the national parties (the Scottish National Party and Plaid Cymru). Indeed, the standardised regression coefficients suggest that defending seats from the Conservatives was a particular strong spur to activity in both cases. More surprising, however, is the finding that Labour members were more active where Labour was challenging the Conservatives. An explanation here is that the raw politics of campaigning matters, and fighting the traditional political enemy of the Conservatives was sufficient to generate greater activity, even if there was a strong likelihood (as there was in 2010) that the Conservatives would win these seats. This was true of supporters as well but only at the $10 \%$ level of significance. For the Liberal Democrats, both supporters and members were more active when challenging the Conservatives (albeit at the $10 \%$ level in the case of supporters). Again, this may be expected - the Conservatives have been the more traditional political enemy of the Liberal Democrats (at least prior to the Coalition). All of these similarities, then, suggest a complementarity of supporter and member activity.

However, there are also some key differences between the predictors of member and supporter activity. There are differences in demographic predictors for all three parties. In the

a copy of the electoral register; preparing the contents of the candidate's election address; making arrangements for printing; identifying potential supporters through canvassing. 
case of the Conservatives, different demographics were relevant for members (proportions of graduates and owner occupiers) compared with supporters (proportion of manual workers). For Labour, while a more ethnically diverse population was a predictor for member activity, it was population density that helped predict supporter activity. And, for the Liberal Democrats, none of the demographics that predicted levels of supporter activity (an ethnically diverse population and proportions of graduates, owner-occupiers and council or housing association tenants) were relevant in the case of members.

Perhaps the most interesting differences are in the case of variables, which come under the heading of politics. In the case of candidate characteristics, we find that Black and Minority Ethnic (BME) candidates boosted Conservative supporter activity but not member activity, while the reverse was true where Labour fielded women candidates. This boosted levels of activity by Labour members, but not Labour supporters (the same was true in the case of the Conservatives, albeit at the $10 \%$ level). Equally interesting is the finding that in seats that Labour was defending from the Liberal Democrats, supporter activity was higher, but member activity was not affected. Given the surge in Liberal Democrat popularity in the runup to the 2010 election, this may help explain why Labour was successful in depressing the Liberal Democrat votes through its constituency campaigning (Fisher, Cutts \& Fieldhouse, 2011b). Left to party members alone, Labour may not have been so successful in these seats, suggesting that in this case at least, supporter activity certainly made a significant independent contribution. Given that member activity was greater is seats where Labour was challenging the Conservatives (where the chances of success were slim), there is also a case to suggest that supporter activity was distributed more effectively than that of members. Overall, coupled with the findings in respect of the impact of candidate characteristics, there is some evidence that the efforts of supporters in general may offer something more than just an extension of members' activities.

\section{[Table 5 About Here] \\ [Table 6 About Here]}

\section{DO SUPPORTERS MAKE AN INDEPENDENT POSITIVE CONTRIBUTION TO CONSTITUENCY CAMPAIGNS?}

Our final question is whether the efforts of supports had independent and positive effects on constituency campaigns. Fisher, Cutts \& Fieldhouse (2011b) show that constituency campaigning in 2010 had demonstrable electoral payoffs. Thus, to assess this question, we regress a measure of overall campaign intensity against the indexes of member and 
supporter activity. Campaign intensity is a measurement derived from the incorporation of ten components of constituency campaigning (preparation, organisation, manpower, use of computers, polling day activity, use of telephones, use of direct mail, canvassing, leaflets and use of e-campaigning). ${ }^{7}$ As we might expect the levels of member and supporter activity are themselves correlated, though perhaps not as strongly as one might expect, ${ }^{8}$ and the models confirm that supporter and member activities had independent effects on overall campaign intensity.

The patterns are similar for all three parties: both member and supporter activities had a statistically significant impact on campaign intensity. The impact of member activity was stronger for all three parties (and in each case, the difference between member and supporter activity is statistically significant). However, once again, we see that supporter activity is nontrivial. Not only did supporter activity have an independent effect, but the change in the value of the F statistic though the introduction of the supporter index is statistically significant in all cases, though the strength varies by party. The impact of supporter activity is strongest in the case of the Liberal Democrats and weakest in the case of the Conservatives. But overall, the picture is clear - the activities of supporters made a positive independent contribution to the intensity of parties' constituency-level campaigns and therefore both complemented and supplemented the activities of members.

\section{[Table 7 About Here]}

\section{CONCLUSIONS}

Previous research on volunteer activity in political parties has frequently focussed exclusively on formal party members. As such, and notwithstanding the observations of Webb (1995), van Biezen et al (2012) and Katz \& Mair (2009), the decline of party members has often been regarded as being an indicator that party organisations are in difficulties, with many associated negative consequences. However, evidence from various countries (including Britain) suggests that parties are increasingly open to (and indeed are encouraging) the involvement of party supporters who are not formal members. Our new evidence from the British general election of 2010 suggests that this may particularly be the

Full details of how the index is calculated can be found in Fisher, Cutts \& Fieldhouse, 2011: 827-8

Levels of supporter and member activity correlated at the .511 level for the Conservatives, .566 for Labour and .598 for the Liberal Democrats. 
case in election campaigns. These analyses have shown that the extent of supporter activity in elections may be much more extensive than might commonly have been thought. Over three quarters of constituency (district level) campaigns in Britain recruited supporters in 2010 and on average, supporters engaged in around two thirds of the activities of members.

In the light of the evident importance of supporters in 2010, our core question sought to address the extent to which supporter activities complemented those of members, or whether they also supplemented them. We examined this with four key tests. In respect of activities undertaken, there was greatest support for the complementarity argument. Supporters engaged in similar activities to those of members, though most similarity was found in respect of low intensity activities (such as delivering leaflets and staffing polling stations). Our second test assessed the degree to which supporter activity was a function of existing active local parties. The findings here were mixed. For the Liberal Democrats, supporter activity complemented active local parties. However, in the case of the Conservatives and Labour, the much weaker relationship suggested that in addition to complementing local parties, supporters also supplemented them to an extent.

Our third test assessed the correlates of member and supporter activity. Again, there was strong evidence of complementarity, with a number of variables predicting higher levels of both member and supporter activity. But there was also some evidence of the activities of supporters supplementing those of members. Finally, we considered the impact of member and supporter activity on the overall level of campaign intensity. The evidence here was very clear. Supporter activity clearly complemented that of members, but the positive and independent effects also indicated that these activities also supplemented those of members in producing stronger campaigns. Supporters would appear to be therefore an extremely important aspect of parties' election activities, complementing, and in place, supplementing the activities of members. Of course, with no previous data about supporter activity at elections, we cannot accurately comment on whether this phenomenon is recent or not. Certainly, neither previous quantitative nor qualitative accounts of election campaigns allude to supporter activity (see, for example, Denver \& Hands, 1997). However, the extent of supporter involvement in all parties that we observe here would suggest that the recruitment of non-members may not have been confined to one or even two recent elections.

In sum, although members clearly still matter, they are not the only source of voluntary activity, especially in election campaigns - to coin a phrase; members are not the only fruit. This suggests an evolution of parties in response to membership decline. It also suggests 
that models of party organisation may require a degree of refinement. Existing models focus on members as the source of volunteer activity. They also only consider members (rather than supporters) in terms of participatory rights and the balances that are struck within party organisations. Yet supporters may be very different. As non-members, for example, they may be content to provide volunteer labour without receiving participatory rights in return. As such, this may question some of the underlying assumptions in important theoretical work such as May's Law of Curvilinear Disparity (1973). If party leaders need pay less attention to the selection and policy-making rights of members, safe in the knowledge that supporters will form part of their electoral volunteer force, this may lead to parties being able to position themselves closer to the desires of their voters, rather than paying so much attention to balancing the desire of voters and activist members. Thus, a growth in the use of supporters coupled with a decline in members may indicate the development of an enhanced form of cadre party or at the very least, greater leadership domination. There is clear precedent here in terms of the research on pressure groups. Jordan and Maloney (1997) show how in some large pressure groups, membership is passive in terms of internal decision-making and is encouraged to be so by the leadership, who enjoy significant autonomy.

A second consequence is one for questions of exit, voice or loyalty. As supporters rather than members, the option of voice may not be available. Equally, the option of exit becomes more vague compared with party membership. Actively leaving a party is a key decision and one that may not be reversed. Any decision to exit or re-join would not be made lightly. With supporters, no such hard decisions are necessary. Supporters may withdraw their labour in the short term, but do not face such hard decisions if they wish to become involved again. This leads us to both the benefits and disadvantages of supporters to parties. On the positive side, parties obviously have a broader pool of voluntary labour upon which to draw. And, issues of exit, voice and loyalty are unlikely to produce the permanent exclusion that may apply to members in the event of an exit. Equally, parties may benefit as electoral maximizers if grassroots voices are less prominent.

However, there may also be negative aspects - especially if there is an over-reliance on supporters as a source of voluntary labour. First, membership may bring with it a greater sense of loyalty. One observation that can be made about the 2010 election in Britain, for example, is that it was a high profile and exciting one, with much at stake for all parties. Such an election may be particularly likely to result in the recruitment of active supporters. All elections are not equally exciting however and we may expect to find that supporters are more difficult to recruit where a party has little chance of success, or where the outcome is very predictable. Certainly, previous research (Fisher, 2000, Fisher, Denver \& Hands, 
2006b) has indicated that such conditions have a detrimental effect on member retention. In such circumstances, the loyalty of members compared with supporters may be of high value. And, of course, it may be that grassroots voices within parties are electorally beneficial especially where they chime closely with the views of a party's voters or potential voters.

These questions are clearly ones to be considered in future research on party organisation, but whatever the implications, these data suggest that the composition of voluntary labour in parties may be more varied. Moreover, as suggested by van Biezen et al (2012), it questions the idea of whether membership decline remains a key indicator of party decline. The analyses presented here suggest that parties may be adapting rather than necessarily failing; and that the apparently extensive role of supporters in party activities appears to point instead to party evolution rather than self-evident decline. 


\section{REFERENCES}

van Biezen, I., Mair, P. and Poguntke, T. (2012) 'Going, going...gone? The decline of party membership in contemporary Europe' European Journal of Political Research. 51 (1): 24-56.

Dalton, R. (1996) Citizen Politics. Second Edition. New Jersey: Chatham House.

Denver, D. and Hands, G. (1997) Modern Constituency Electioneering. London: Frank Cass.

Denver, D., Hands, G. and Fisher, J. (2001) Constituency Campaigning in the 2001 General Election ESRC Award R000239396.

Denver, D., Hands, G., Fisher, J. and MacAllister, I. (2003) 'Constituency Campaigning in Britain 1992-2001: Centralisation and Modernisation' Party Politics. 9 (5): 541-59.

Fisher, J.. (2000) 'Small Kingdoms and Crumbling Organisations: Examining the Variation in Constituency Party Membership and Resources' British Elections \& Parties Review. 10:133-150.

Fisher, J. (2002) 'Political Parties: Organisational Change and Intra Party Democracy' in, Fisher, Denver \& Benyon (eds) Central Debates in British Politics. Harlow: Longman, pp. 137-56.

Fisher, J. (2011) 'Legal regulation and political activity at the local level in Britain' in Ewing, Tham \& Rowbottom (eds) The Funding of Political Parties. London: Routledge.

Fisher, J. (2008) 'Whither the Parties?' in Hazell (Ed) Constitutional Futures Revisited Basingstoke: Palgrave. pp. 249-66.

Fisher, J., Denver, D., \& Hands, G. (2006a) 'The Relative Electoral Impact of Central Party Co-ordination and Size of Party Membership at Constituency Level' Electoral Studies. 25 (4): 664-76.

Fisher, J., Denver, D., \& Hands, G. (2006b) 'Party Membership and Campaign Activity in Britain: The Impact of Electoral Performance' Party Politics. 12 (4): 505-19. 
Fisher, J. \& Denver, D. (2008) 'From Foot-Slogging to Call Centres and Direct Mail: A Framework for Analysing the Development of District-Level Campaigning'. European Journal of Political Research. 47 (6):794-826.

Fisher, J. \& Denver, D. (2009) 'Evaluating the Electoral Effects of Traditional and Modern Modes of Constituency Campaigning in Britain 1992-2005' Parliamentary Affairs. 62 (2):196-210.

Fisher, J., Cutts, D. \& Fieldhouse, E. (2011a) 'Constituency Campaigning in 2010' in Wring, Mortimore \& Atkinson (eds) Political Communication in Britain: TV Debates, the Media and the Election. Basingstoke: Palgrave, pp.198-217.

Fisher, J., Cutts, D. \& Fieldhouse, E. (2011b) 'The Electoral Effectiveness of Constituency Campaigning in the 2010 British General Election: The 'Triumph' of Labour?' Electoral Studies. 30 (4): 816-28.

Gauja, A. (2009) 'Moving Beyond the Membership? The Transformation of Party Organisations, Policy Outsourcing and the Creation of Supporters' Networks' Paper presented at the Annual Conference of the American Political Science Association, Toronto.

Hazan, R.Y. \& Rahat, G. (2010) Democracy within Parties. Oxford: Oxford University Press.

Hopkin, J. (2001) 'Bringing the Members Back In? Democratizing Candidate Selection in Britain and Spain' Party Politics. 7 (3): 343-61.

Horton, T., Pinto-Duschinsky, D. \& Studdert, J. (2007) Facing Out. London: Fabian Society.

Institute for Government (2011) Party People. London: Institute for Government.

Jordan, G. \& Maloney, W. (1997) The Protest Business: Mobilizing Campaign Groups. Manchester: Manchester University Press.

Katz, R.S. \& Kolodny, R. (1994) 'Party Organization as an Empty Vessel: Parties in American Politics' in Katz \& Mair (eds) How Parties Organize. London: Sage. pp 2350. 
Katz, R.S. and Mair, P. (2009) 'The Cartel Party Thesis: A Restatement' Perspectives in Politics 7 (4): 753-766.

The Labour Party (2011a) Refounding Labour. London: The Labour Party.

The Labour Party (2011b) Refounding Labour to win. London: The Labour Party.

Lawson, K. \& Merkl, P. (1988) When Parties Fail: Emerging Alternative Organisations. Princeton N.J.: Princeton University Press.

Mair, P. \& van Biezen, I (2001) 'Party Membership in Twenty European Democracies' Party Politics. 7 (1): 5-21.

Maor, M. (1997) Political Parties \& Party Systems. London: Routledge.

May, J.D. (1973) 'Opinion structure of political parties: the special law of curvilinear disparity' Political Studies. 21 (2): 135-51.

Mcllveen, R. (2009) 'Ladies of the Right: An Interim Analysis of the A-List' Journal of Elections, Public Opinion \& Parties. 19 (2):147-157.

Paterson, P. (1967) The Selectorate. London: MacGibbon \& Kee.

Phillips, H. (2007) Strengthening Democracy: Fair and Sustainable Funding of Political Parties.

The Review of the Funding of Political Parties. London: HMSO.

Russell, M. (2005) Building New Labour. Basingstoke: Palgrave.

Scarrow, S.E. (1996) Parties and Their Members: Organising for Victory in Britain and Germany. Oxford: Oxford University Press.

Scarrow, S. E. (2000) 'Parties without Members? Party Organisation in a Changing Electoral Environment' in Dalton \& Wattenburg (eds) Parties without Partisans. Oxford: Oxford University Press pp.79-101. 
Seyd, P. \& Whiteley, P. (1992) Labour's Grassroots. Oxford: Clarendon.

Seyd, P. \& Whiteley, P. (2002) New Labour's Grassroots. Basingstoke: Palgrave.

Ware, A. (1996) Political Parties and Party Systems. Oxford: Oxford University Press.

Webb, P. (1995) 'Are British Political Parties in Decline?’ Party Politics. 1 (3): 299-322.

Whiteley, P. (2011) 'Is the party over? The decline of party activism and membership across the democratic world' Party Politics. 17 (1): 21-44.

Whiteley, P. and Seyd, P., (2003), 'How to win a landslide by really trying: the effects of local campaigning on voting in the 1997 British general election', Electoral Studies. 22 (2): 301-24.

Whiteley, P., Seyd, P., \& Richardson, J. (1994) True Blues. Oxford: Clarendon.

Whiteley, P., Seyd, P., \& Billinghurst, A. (2005) Third Force Politics. Oxford: Oxford University Press. 
Table 1. Supporter Recruitment by Party

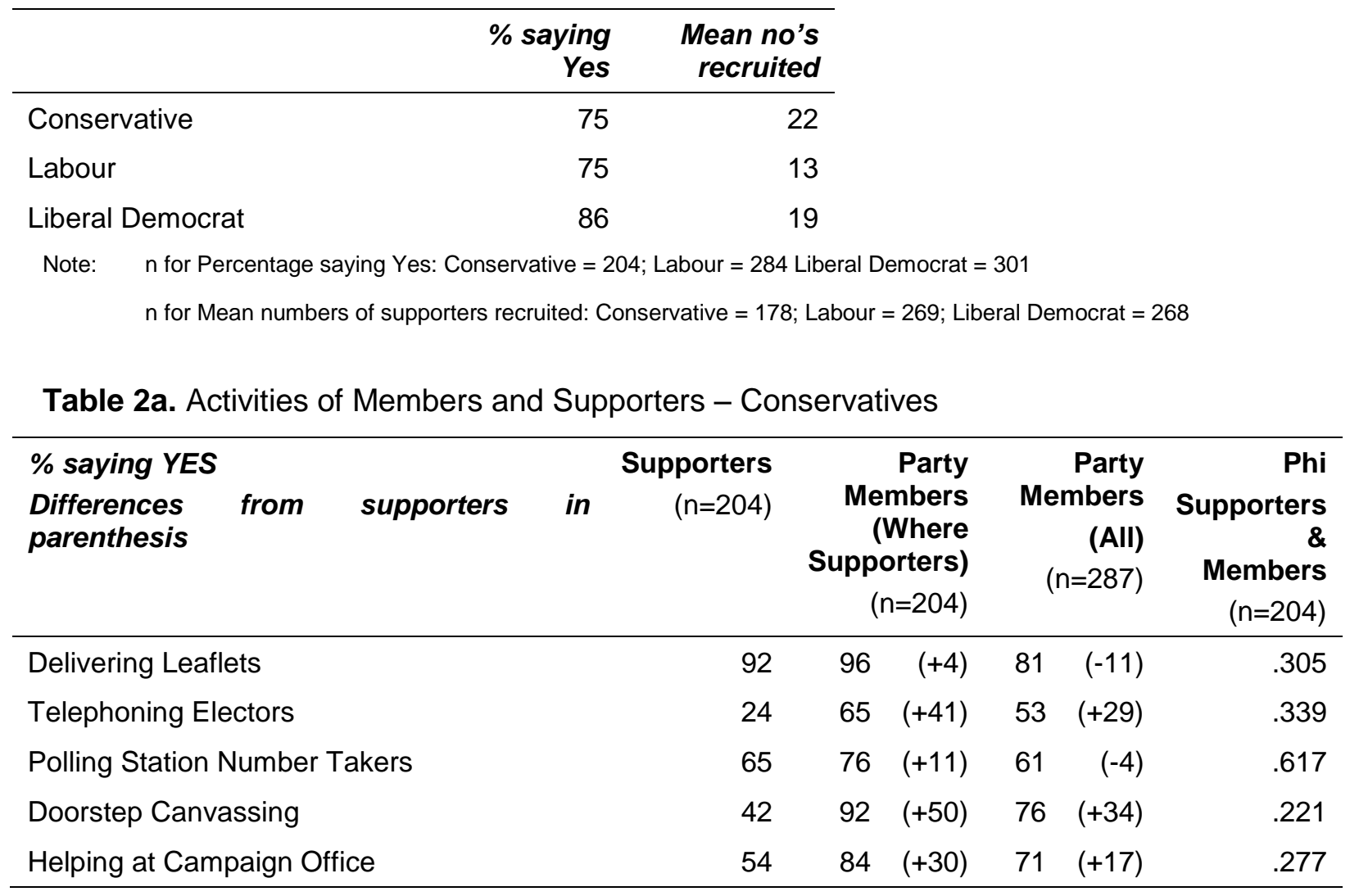

Table 2b. Activities of Members and Supporters - Labour

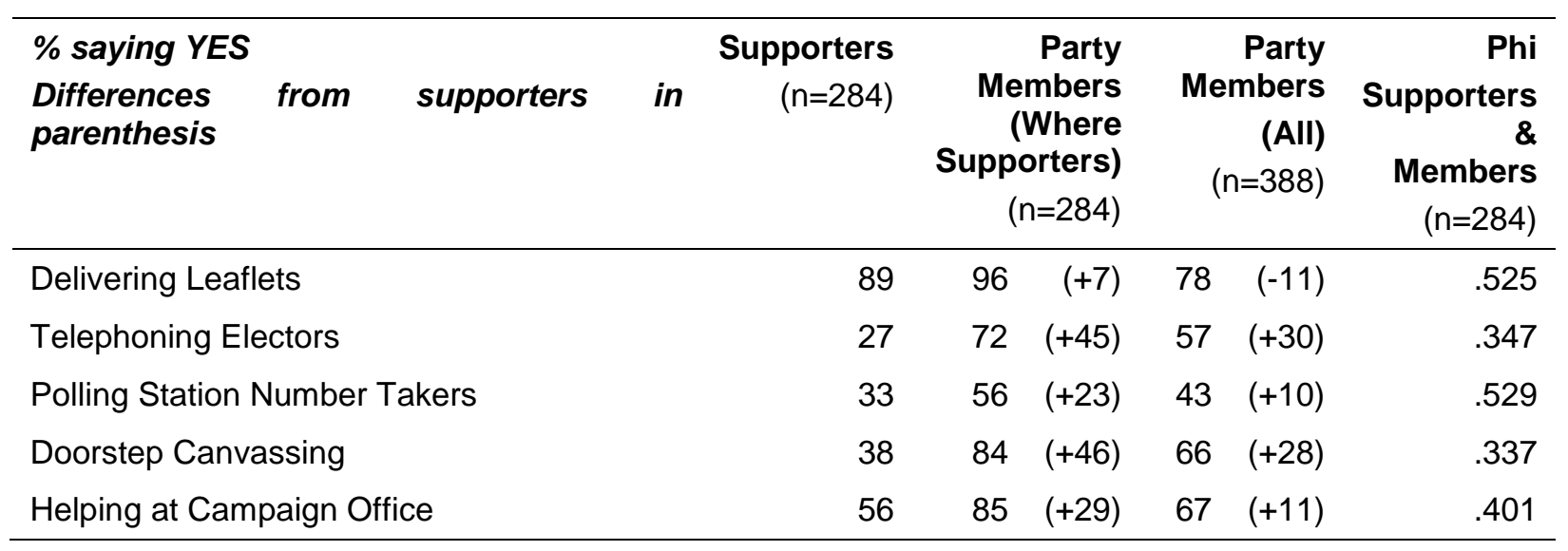


Table 2c. Activities of Members and Supporters - Liberal Democrats

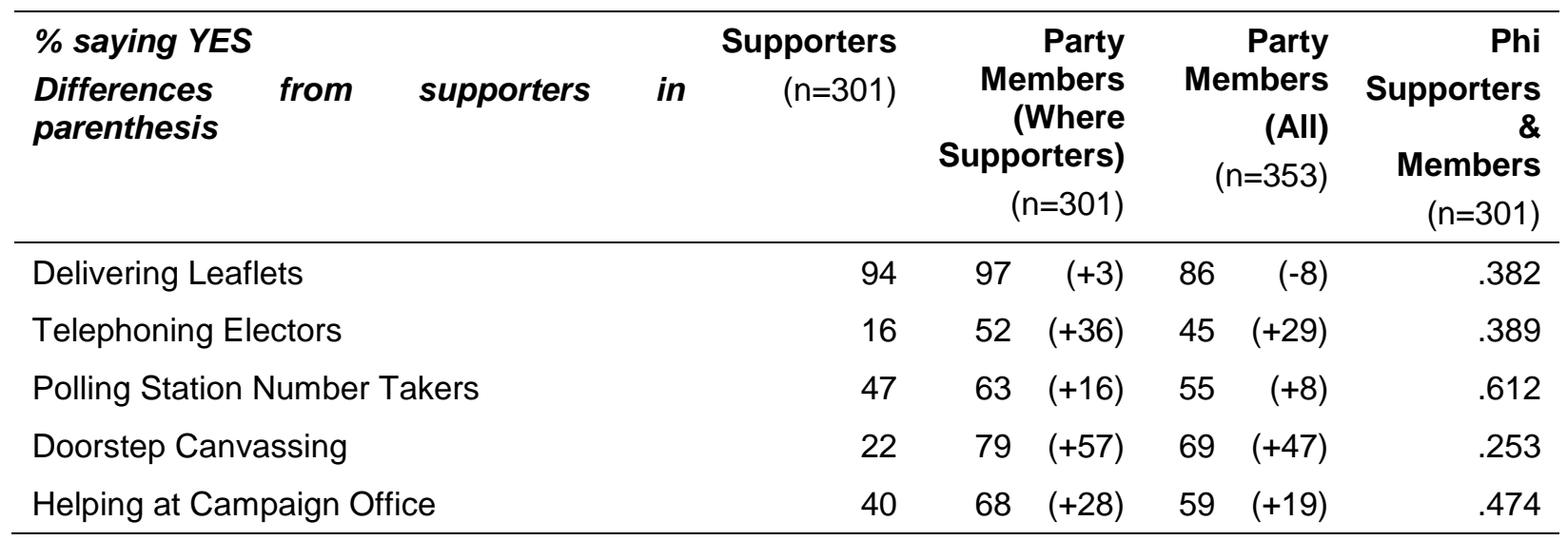

Table 3. Member and Supporter Activity Means (Where Supporters Recruited)

\begin{tabular}{lrrr}
\hline & Members & Supporters & Proportion \\
\hline Conservative $(\mathrm{n}=204)$ & 4.1 & 2.8 & .68 \\
Labour $(\mathrm{n}=284)$ & 3.9 & 2.4 & .64 \\
Liberal Democrat $(\mathrm{n}=301)$ & 3.6 & 2.2 & .63 \\
\hline
\end{tabular}

Proportion - Proportion of Supporter Activity to Member Activity

Table 4. Existing Membership Strength and Supporter Activity

\begin{tabular}{|c|c|c|c|c|c|c|c|c|c|}
\hline \multirow{2}{*}{$\begin{array}{l}\text { Dependent Variable = } \\
\text { Level of Supporter Activity } \\
\text { Constant }\end{array}$} & \multicolumn{4}{|c|}{$\begin{array}{r}\text { Conservative } \\
\qquad(n=154)\end{array}$} & \multicolumn{3}{|c|}{$\begin{array}{l}\text { Labour } \\
(n=220)\end{array}$} & \multicolumn{2}{|c|}{$\begin{array}{r}\text { Lib Dems } \\
(n=214)\end{array}$} \\
\hline & 2.496 & $(.223)$ & *** & 1.977 & $(.184)$ & $* * *$ & 1.223 & $(.156)$ & $* * *$ \\
\hline No. of Party Members & n.s. & & & n.s. & & & .004 & $(.001)$ & $* * *$ \\
\hline$\%$ Covered by Active Local Org. & .009 & $(.004)$ & ** & .011 & $(.003)$ & $* \star *$ & .013 & $(.004)$ & $\star \star *$ \\
\hline Adj. $R^{2}$ & & .022 & & & .051 & & & .238 & \\
\hline
\end{tabular}

Note 1: Coefficients are unstandardised $b$ values.

Note $2:{ }^{* * *} p<.01{ }^{* *} p<.05$ n.s not statistically significant; 
Table 5. Predictors of Supporter Activity

\begin{tabular}{|c|c|c|c|c|c|c|c|c|c|c|c|c|}
\hline & \multicolumn{4}{|c|}{$\begin{array}{c}\text { Conservative } \\
(n=204)\end{array}$} & \multicolumn{4}{|c|}{$\begin{array}{l}\text { Labour } \\
(n=284)\end{array}$} & \multicolumn{4}{|c|}{$\begin{array}{l}\text { Lib Dems } \\
(\mathrm{n}=301)\end{array}$} \\
\hline & $b$ & Beta & Std Err & Sig. & $b$ & Beta & Std Err & Sig. & $b$ & Beta & Std Err & Sig. \\
\hline Constant & n.s. & & & & n.s. & & & & 11.173 & & $(2.784)$ & $* * *$ \\
\hline$\%$ White & n.s. & & & & n.s. & & & & -.029 & -.220 & $(.010)$ & *** \\
\hline$\%$ Manual Workers & .101 & .391 & $(.042)$ & ** & n.s. & & & & n.s. & & & \\
\hline$\%$ Prof \& Managerial & n.s. & & & & n.s. & & & & n.s. & & & \\
\hline$\%$ No Qualifications & n.s. & & & & n.s. & & & & n.s. & & & \\
\hline$\%$ Students & n.s. & & & & n.s. & & & & n.s. & & & \\
\hline$\%$ with Degree & n.s. & & & & n.s. & & & & -.056 & -.332 & $(.027)$ & ** \\
\hline$\%$ Owner Occupiers & n.s. & & & & n.s. & & & & -.049 & -.376 & $(.022)$ & ** \\
\hline$\%$ Council / HA & n.s. & & & & n.s. & & & & -.051 & -.335 & $(.023)$ & ** \\
\hline Persons Per Hectare & n.s. & & & & .015 & .251 & $(.006)$ & ** & n.s. & & & \\
\hline Con / Lib Dem Seat & n.s. & & & & $\mathrm{n} / \mathrm{a}$ & & & & .341 & .105 & $(.197)$ & * \\
\hline Lib Dem / Con Seat & n.s. & & & & $\mathrm{n} / \mathrm{a}$ & & & & n.s. & & & \\
\hline Con / Lab Seat & n.s. & & & & .409 & .123 & $(.218)$ & * & $\mathrm{n} / \mathrm{a}$ & & & \\
\hline Lab / Con Seat & n.s. & & & & .836 & .307 & $(.284)$ & $* * *$ & $\mathrm{n} / \mathrm{a}$ & & & \\
\hline Lab / Lib Dem Seat & $\mathrm{n} / \mathrm{a}$ & & & & .639 & .186 & $(.314)$ & ** & n.s. & & & \\
\hline Lib Dem / Lab Seat & $\mathrm{n} / \mathrm{a}$ & & & & n.s. & & & & n.s. & & & \\
\hline Lab / Nat Seat & $\mathrm{n} / \mathrm{a}$ & & & & 1.628 & .228 & $(.462)$ & $* * *$ & $\mathrm{n} / \mathrm{a}$ & & & \\
\hline Candidate Sex & n.s. & & & & n.s. & & & & n.s. & & & \\
\hline Candidate Race & 1.054 & .209 & $(.342)$ & *** & n.s. & & & & n.s. & & & \\
\hline Level of Preparation & .171 & .332 & $(.039)$ & *** & .106 & .201 & $(.031)$ & $* * *$ & .120 & .272 & $(.025)$ & $* * *$ \\
\hline Target Seat & .439 & .150 & $(.253)$ & * & n.s. & & & & .790 & .228 & $(.333)$ & ** \\
\hline Adj. $R^{2}$ & & & & .192 & & & & .294 & & & & .308 \\
\hline
\end{tabular}

Note 1: Coefficients are unstandardised $b$ values.

Note $2:{ }^{* \star *} p<.01{ }^{* \star} p<.05{ }^{*} p<.10$ n.s not statistically significant; n/a not applicable 
Table 6. Predictors of Member Activity

\begin{tabular}{|c|c|c|c|c|c|c|c|c|c|c|c|c|}
\hline & \multicolumn{4}{|c|}{$\begin{array}{l}\text { Conservative } \\
\qquad(n=204)\end{array}$} & \multicolumn{4}{|c|}{$\begin{array}{l}\text { Labour } \\
(n=284)\end{array}$} & \multicolumn{4}{|c|}{$\begin{array}{l}\text { Lib Dems } \\
\qquad(n=301)\end{array}$} \\
\hline & $b$ & Beta & Std Err & Sig. & $b$ & Beta & Std Err & Sig. & $b$ & Beta & Std Err & Sig. \\
\hline Constant & 9.828 & & (3.259) & $* * *$ & 6.265 & & $(2.684)$ & ** & 6.615 & & $(2.746)$ & ** \\
\hline$\%$ White & -.015 & -.176 & $(009)$ & * & -.022 & -.167 & $(.009)$ & ** & n.s. & & & \\
\hline$\%$ Manual Workers & n.s. & & & & n.s. & & & & n.s. & & & \\
\hline$\%$ Prof \& Managerial & n.s. & & & & n.s. & & & & n.s. & & & \\
\hline$\%$ No Qualifications & n.s. & & & & n.s. & & & & n.s. & & & \\
\hline$\%$ Students & -.054 & -.183 & $(.028)$ & * & n.s. & & & & n.s. & & & \\
\hline$\%$ with Degree & -.066 & -.457 & $(.034)$ & ** & n.s. & & & & n.s. & & & \\
\hline$\%$ Owner Occupiers & -.049 & -.514 & $(.024)$ & ** & n.s. & & & & n.s. & & & \\
\hline$\%$ Council / HA & n.s. & & & & n.s. & & & & n.s. & & & \\
\hline Persons Per Hectare & -.012 & -.247 & $(.006)$ & * & n.s. & & & & n.s. & & & \\
\hline Con / Lib Dem Seat & n.s. & & & & $\mathrm{n} / \mathrm{a}$ & & & & .655 & .187 & $(.194)$ & *** \\
\hline Lib Dem / Con Seat & n.s. & & & & $\mathrm{n} / \mathrm{a}$ & & & & n.s. & & & \\
\hline Con / Lab Seat & n.s. & & & & .428 & .130 & $(.197)$ & ** & $\mathrm{n} / \mathrm{a}$ & & & \\
\hline Lab / Con Seat & n.s. & & & & .938 & .349 & $(.257)$ & *** & $\mathrm{n} / \mathrm{a}$ & & & \\
\hline Lab / Lib Dem Seat & $\mathrm{n} / \mathrm{a}$ & & & & n.s. & & & & n.s. & & & \\
\hline Lib Dem / Lab Seat & $\mathrm{n} / \mathrm{a}$ & & & & n.s. & & & & n.s. & & & \\
\hline Lab / Nat Seat & $\mathrm{n} / \mathrm{a}$ & & & & 1.162 & .165 & $(.417)$ & $* * *$ & $\mathrm{n} / \mathrm{a}$ & & & \\
\hline Candidate Sex & .291 & .103 & $(.175)$ & * & .343 & .124 & $(.130)$ & $* * *$ & n.s. & & & \\
\hline Candidate Race & n.s. & & & & n.s. & & & & n.s. & & & \\
\hline Level of Preparation & .130 & .272 & $(.034)$ & $* * *$ & .197 & .379 & $(.028)$ & *** & .195 & .413 & $(.025)$ & *** \\
\hline Target Seat & .752 & .278 & $(.223)$ & $* * *$ & n.s. & & & & .596 & .160 & $(.328)$ & * \\
\hline Adj. $R^{2}$ & & & & .268 & & & & .410 & & & & .417 \\
\hline
\end{tabular}

Note 1: Coefficients are unstandardised $b$ values.

Note $2:{ }^{* *} p<.01{ }^{* *} p<.05^{*} p<.10$ n.s not statistically significant; $n / a$ not applicable 
Table 7. Relative Impact of Supporter and Member Activity on Campaign Intensity

\begin{tabular}{|c|c|c|c|c|c|c|c|c|c|c|c|c|}
\hline & \multicolumn{4}{|c|}{$\begin{array}{l}\text { Conservative } \\
\qquad(n=204)\end{array}$} & \multicolumn{4}{|c|}{$\begin{array}{l}\text { Labour } \\
(n=284)\end{array}$} & \multicolumn{4}{|c|}{$\begin{array}{l}\text { Lib Dems } \\
\quad(n=301)\end{array}$} \\
\hline & $b$ & Beta & Std Err & Sig. & $b$ & Beta & Std Err & Sig. & $b$ & Beta & Std Err & Sig. \\
\hline Constant & 53.622 & & $(6.511)$ & $* * *$ & 47.981 & & $(4.281)$ & $* \star \star$ & 37.623 & & (3.775) & $* \star *$ \\
\hline $\begin{array}{l}\text { Level of Member } \\
\text { Activity }\end{array}$ & 12.242 & .455 & $(1.754)$ & $* * *$ & 11.084 & .475 & $(1.256)$ & $* \star *$ & 10.950 & .460 & (1.224) & $* * *$ \\
\hline $\begin{array}{l}\text { Level of Supporter } \\
\text { Activity }\end{array}$ & 5.802 & .233 & (1.627) & $* * *$ & 6.356 & .275 & $(1.242)$ & $* * *$ & 8.268 & .323 & (1.315) & $\star * *$ \\
\hline$R^{2}$ & \multicolumn{4}{|c|}{.363} & \multicolumn{4}{|c|}{.446} & \multicolumn{4}{|c|}{.491} \\
\hline
\end{tabular}

Note 1: Coefficients are unstandardised $b$ values.

Note 2: *** $p<.01$

\section{APPENDIX}

Table A1: Responses

The numbers of responses for each party by target status were as follows:

\begin{tabular}{lllll}
\hline & All & Held Not Target & Target & $\begin{array}{l}\text { Not Target Not } \\
\text { Held }\end{array}$ \\
\hline Conservative & 287 & 120 & 56 & 111 \\
Labour & 388 & 129 & 74 & 185 \\
Liberal Democrat & 353 & $*$ & 50 & 303 \\
\hline
\end{tabular}

Table A2: Mean Percentage of Maximum Spend by Responses During Long and Short Campaigns

\begin{tabular}{lrr}
\hline$\%$ & Respondents & All Constituencies \\
\hline Conservative & 37.2 & 38.1 \\
Labour & 22.5 & 25.6 \\
Liberal Democrat & 18.8 & 19.6 \\
\hline
\end{tabular}

